\title{
Economic Considerations of Legal Delimitation: Evidence from Judicial Verdicts in Bangladesh Courts
}

\author{
Mohammad Dulal Miaha, Mohammed Usman ${ }^{\mathrm{b}} \&$ Yasushi Suzukic
}

\begin{abstract}
The literature on law and economics argues that economic considerations have an important implication for consistent and efficient legal practices. In line with this tradition, this paper aims to analyse legal verdicts through the lens of transaction cost to ascertain if judicial decision takes social cost into account. In so doing, the research draws upon the literature of transaction cost theory, which examines the implications of transaction cost for legal verdicts. Data for the analysis consist of legal verdicts collected from Bangladesh. The paper shows that judicial decisions are influenced by economic matters, especially social and transaction costs. When the issue of these costs is clear, judges take this into consideration in deciding who should own what rights. This research contributes to the literature of law and economics by providing new information, which is believed to help regulators, policymakers, and legal practitioners in deciding valuecreating property rights.
\end{abstract}

Keywords: Property rights; Transaction cost; Externality; Rights attenuation; Regulatory takings.

JEL Classification: D23, K11, K15

a Corresponding author. Department of Economics and Finance, University of Nizwa, Birkat Al Mawz, Nizwa, Oman.E-mail: dulal@unizwa.edu.om, ORCiD: 0000-0001-9545-837X

b Department of Management, University of Nizwa, Birkat Al Mawz, Nizwa, Oman. Email: usman@unizwa.edu.om, ORCiD: 0000-0003-2120-1170

c Professor, College of International Management, Ritsumeikan Asia Pacific University, Beppu, Japan.Email: szkya@apu.ac.jp, ORCiD: 0000-0002-3939-6917 


\section{Introduction}

The development of the field of law and economics in the last couple of decades has heralded the view that judicial decisions are not merely a concern of social justice, morality and fairness; but rather, that legal verdicts take economic efficiency, especially the consideration of social cost, into account. Traditionally, the application of law in the field of economics was confined to some limited areas including anti-trust law, taxation, regulated industry, and monetary damages (Cooter and Ulen, 2016; Barrere, 2004; Cass, 2004). However, since the beginning of the 1960s, the scope of the economic analysis of law expanded to new avenues, particularly, to property rights (Coase, 1960; Barzel, 1997; Calabresi, 1961; Posner, 2002).

The primary issue of property rights analysis underlies the question: who owns what rights, and how are these rights allocated. In a capitalist economic system, resources are allocated through the price mechanism. However, the market is unable to determine the true exchange value of many resources (Demsetz, 1964; 1966). For example, the exchange value of an open fish reservoir, a newly discovered mine of mineral resources, forest lands, artistic expression, such as the paintings of Van Gogh or Leonardo da Vinci and radio spectrum allocation. is hard to determine by the traditional market mechanism. An alternative, such as an auction mechanism (Milgrom, 2004; Milgrom and Weber, 1982), lottery system (Taylor et al., 2003; Boyce, 1994), or the judicial arrangement (Coase, 1960; Libecap, 1989), can allocate rights on these resources.

In his seminal work, The Problem of Social Cost, Ronald H. Coase convincingly argues that allocation process does not matter for efficiency if the transaction cost is zero (Coase, 1960). Assume that a particular radio spectrum is initially allotted to A. However, B values the rights on the spectrum more than A. Such an inefficient allocation does not hinder social efficiency because B, for his own interest, would offer a price to A to buy the spectrum rights. A, for his own interest, would accept the offer. Such a transaction ensures social efficiency. However, the said transaction ceases to exist if the cost of the transaction is high. Based on this logic, Coase (1960) argues that a particular pattern of property right allocation results in different social outcomes if the cost of transaction is high. Coase illustrates several English cases to demonstrate that judges, as an initial allocator of rights, consider the economic consequences of legal decisions. This paper aims to 
contribute to this strand of literature. It analyses judicial decisions, through the lens of transaction cost, to ascertain if judicial decision take economic aspects into account.

The contribution of this paper is novel. First, this study is the first to provide evidence concerning economic consequences of legal delimitation in the context of Bangladesh. Although a Coasean analytical framework has been applied extensively in the context of developed economies (Bertrand, 2006; Foray and Woerter, 2020; Slaev and Daskalova, 2020; Candela and Geloso, 2019), such an analysis is comparatively scarce in the case of developing economies, in general, and Bangladesh, in particular. Second, the paper provides fresh evidence to the literature of institutional economics. The field of law and economics is emerging owing to the relevance of the field to practical decision-making (Hylton, 2019; Jolls et al., 1998; McCluskey et al., 2016). Hence, the current study aims to contribute to the existent literature by providing new evidence. Third, economic analysis of legal delimitation can offer some practical implications for legal practitioners and policymakers. For example, legal delimitation may yield very different social consequences in the presence or absence of high transaction costs.

The structure of this paper is as follows: section two enumerates the objectives of the paper whereas section three discusses the methodology. Section four describes the transaction cost theory as an analytical framework with an emphasis on the impact of transaction cost on the initial allocation of rights. Section five analyses the legal cases. We provide evidence from an array of cases including first possession, attenuation of rights, and public nuisance. This is followed by a conclusion.

\section{Research Objectives}

Following the works of Ronald Coase (1959, 1960), numerous studies have analysed the economic implications of judicial decisions related to property rights allocation (Cooter and Rubinfeld, 1989; Kaplow, 1986; Kornhauser, 1985; Polinsky, 2019; Epstein and Knight, 2017). The objective of this study is to contribute to this stream of literature by providing an economic analysis of legal delimitation. In other words, this study aims to examine if the judicial decision regarding property rights allocation takes social cost into account in the context of Bangladesh. Moreover, the study also assesses the impact of initial allocation on economic and social efficiency. 


\section{Data and Methodology}

To achieve the objectives stated in Section 2, the study relies on case studies especially, legal lawsuits, related to the issue of property rights. Our choice of analysing legal lawsuits has been motivated by the fact that the legal lawsuit is frequently used in the property rights analysis as a reference. Coase (1960) argues that the initial definition of rights is accomplished most efficiently through the use of government organs such as courts and legislatures. In this sense, legal cases provide us with the necessary information for analysing the nature and consequence of property rights in Bangladesh. In our sample cases, if it is found that a court reverses an existing structure of property rights, we then analyse the background information to figure out the factors that motivated initially to create such an inefficient right. In other words, we analyse the determinants that governed the initial misallocation of rights and the facts that motivated the change in existing rights. We introduce transaction cost theory as an analytical framework to figure out this information. Moreover, we have attempted to cover a wide range of cases, which helps us capture the multifaceted dimensions of property rights analysis.

\section{Transaction Cost and Initial Allocation}

Any analysis of transaction cost starts with the influential work of Ronald Coase, The Problem of Social Cost, which states that when rights are well defined, and transaction is costless, the initial assignment of property rights does not matter for efficient allocation of resources. In explaining this circumstance, he illuminates two powerful dimensions of property rights analysis that matter for efficient allocation of resources - social cost or externality and transaction cost. In the absence of transaction cost all externalities can be internalised. In other words, private and social costs coincide.

Coase (1960) clarifies the logic through an example. There are two pieces of land adjacent to each other; one owned by a farmer for crop production and the other by a rancher for meat production. Their activities produce some externalities, such that an increase of cattle in the herd destroys crops of the neighboring farm. Additional meat production is the expected gain from increased cattle that imposes a negative externality on the farmer by decreasing crop production. In this circumstance, if the 
initial right is assigned to the rancher, it is the farmer who should offer compensation to rancher for not increasing cattle. The farmer would offer an amount less than or equivalent to the crop loss caused by an increase of cattle in the herd. The rancher would accept the offer as long as the amount of compensation amounts to no less than an amount gained from increasing meat from additional cattle.

In this simplified example, it does not matter whether the initial right is owned by the rancher or the farmer (in the Coasean term, rule of liability doesn't matter). The parties involved in this event reach an agreement through a process of bargaining. The bargaining process will lead the rights to be acquired by those who value the property most. This very simplistic view turns into a complex one if we introduce transaction costs. Transaction cost comprises the cost of searching for the affected interacting parties, negotiating among them, writing a contract, monitoring parties to stay up to the spirit of the contract, and any ex-post cost of dispute resolution. In reality, the cost of transaction is not zero. In the presence of high transaction cost, judicial verdicts for allocating rights (initial allocations through the legal system) determine the economic consequences. In other words, the legal delimitation of rights should make economic sense in the question of efficiency if the transaction cost is significant (Coase, 1960).

Referring to the Coase's rancher versus farmer example, let us assume that the additional meat production resulting from the increase of an additional cattle in the herd amounts to $\$ 100$. Such an increase of cattle in the herd destroys the crops equivalent to say $\$ 50$. If the initial right is allocated to the rancher, farmer would accept the loss $(\$ 50)$, which turns into a social cost of ranching. At the aggregate, society gains $\$ 50$ net ( $\$ 100$ gain from the meat production and $\$ 50$ loss from the damage of crops). Conversely, if the initial right is assigned to the farmer, he can resist the rancher from increasing one more cattle in the herd. The social cost of farming amounts to $\$ 100$ (foregone opportunity of increasing one extra cattle for meat production). Since the farmer produces crops amounting to $\$ 50$ in the absence of additional cattle, which can generate $\$ 100$, social loss nets $\$ 50$. However, the rancher can simply acquire the right from the farmer by compensating him an amount equivalent to the monetary value of crops $(\$ 50)$. The rancher still can pocket the remaining $(\$ 100-\$ 50=\$ 50)$. Society gains as a result.

Let us introduce transaction costs at this stage. First, the rancher has to find the counterparty. The cost of searching the counterparty would be 
prohibitive if multiple parties are involved with the transaction. Second, they must negotiate the agreed upon price for exchange value, which, in the realworld scenario, requires professional services and a substantial cost. Third, an accurate assessment of the amount of property loss is seriously difficult, especially when the property in question is multidimensional, such as quality of air, radio spectrum and mineral resources. Finally, the monitoring cost incurred to ensure that the contract is honored or the ex-post cost of dispute resolution in case of deviation from the contract may turn astronomical. Assume that the cost of transaction amounts to $\$ 60$. In such a circumstance, if the right is allocated to the farmer, the rancher finds the deal unattractive $(\$ 100-\$ 50-\$ 60=-\$ 10)$. Thus, the alteration of rights through the market system collapses. Society suffers, as a result. In such a circumstance, Coase argues that the rule of liability matters. For instance, if the initial right is allocated to rancher, society gains overall. Hence, in the presence of high transaction cost, initial allocation matters for efficiency.

Since the publication of Coase's seminal paper, transaction cost theory has been applied to various legal issues. For example, Posner (1973) and Ehrlich and Posner (1974) apply the economic analysis of legal rulemaking and administration procedures, where they show that cost minimisation is the primary concern in deciding between precision and generality in the formulation of legal rules and standards. Djørup (2020) analyses the viability of Danish decarbonisation energy policy through the lens of Coasean transaction cost. Womble and Hanemann (2020) bring a similar issue to our study and show that high transaction costs due to uncertain property rights in Colorado prohibited efficient allocation of water resources. Cai (2020) applies transaction cost approach to analyse the efficiency of tax dispute resolution through the system of tax arbitration and adjudication. Hahn and Stavins (2011) apply the Coasean theory to analyse the efficient allocation of emission trading through the cap-and-trade system. Recent literature also focuses on applying transaction cost theory to the transfer of agriculture farmland (Gao et al., 2019), designing corporate law (Almlöf and Bjuggren, 2019), and low carbon technologies (Mundaca et al., 2013).

Our study extends the above line of research and provides new insights to the application of transaction cost in analysing legal verdicts. Our study also adds to the prior literature that has been dedicated to analysing legal issues from a transaction cost perspective, drawing evidence from a developing country, Bangladesh. Transaction cost is pervasive in 
most developing countries due to the comparatively inefficient nature of institutions (North, 1990). Hence, initial allocation bears an important repercussion for efficient allocation of resources.

\section{Analysis of Judicial Verdicts}

\subsection{First-possession vs. transaction cost}

Over a period of time, the method of first possession has been considered one of the most dominant methods of establishing property rights (Berger, 1985; Epstein, 1979; Rose, 1985). The first possessor is granted ownership or control much before other possible or potentials. Ellickson (1991) argues that first position was a powerful tool of property rights allocation among the early settlers of Anglo-American society. In fact, the concept of first possession has been a fundamental component of ancient societies, including traditional African and Islamic legal systems (Dukeminier and Krier, 1993). However, Coase discusses that the first-possession rule is sometimes ignored in the presence of high transaction costs. Coase presented several legal cases to illustrate the importance of initial allocation and how the legal system reacts to transaction cost. One of such cases is the Kersey vs. City of Atlanta (Coase, 1960:25). ${ }^{1}$

Mr. Kersey purchased a piece of land and built a house on it. After some years, the City of Atlanta constructed an airport adjacent to the house of Mr. Kersey. The plaintiff complained that after the construction of the airport the intensity of dust and noise increased, and the low flying of airplanes rendered his property unsuitable to be used as home. In their verdict, the judges argued that the noise and dust are incidental to the proper operation of an airport and hence cannot be constituted nuisance. However, for the complaint against the low flying operations of the airport, the judges had different opinions:

...can it be said that flights ... at such a low height as to be imminently dangerous to ... life and health ... are necessary concomitant of an airport? We do not think this question can be answered in the affirmative. No reason appears why the city could not obtain lands of an area [sufficiently large] ... as not to require such a low flight. 
The court's view was that the residents including Mr. Kersey had been already living in the place where the airport was built subsequently. If the airport requires low-flying operations, residential areas are not the right choices to construct an airport. This verdict recognises the initial right of the residents by the law of first possession. However, the court further argued that " $\ldots$ if it is indispensable to the public interest that the airport should continue to be operated in its present condition, it may be said that the petitioner should be denied injunctive relief'.

Coase interpreted the above verdict through the lens of transaction cost. He viewed that the court wanted to avoid the greater harm under the excuse of public interest. If, for example, injunction relief was granted to Mr. Kersey, the airport had to relocate in another place in which case social cost would have been enormous. As an alternative, the airport must offer compensation to the residents so that they can leave the noisy and dusty area and relocate in a place which they may consider more peaceful. However, reaching an agreed upon compensation through bargaining, with so many residents involved, would incur huge transaction cost. In contrast, it would be easier, from a social point of view, to decide if Mr. Kersey accepts the noise and dust resulting from the usual operation of the airport or if he was relocated in a better area.

A similar case is reported in the Supreme of Court of Bangladesh. In A Rouf Chowdhury and another vs. Bangladesh and Others (Rajuk) ${ }^{2}$, the plaintiffs were the owners of 'Rangs Bhaban (building)', a 22-storied shopping-cum office building situated nearby an airport, which was built upon receiving appropriate approval from the concerned authority (City Development Authority). While the Rangs building was completed up to $16^{\text {th }}$ floor, objection was raised by the Bangladesh Air Force Head Quarter requesting Rajuk to demolish any adjacent high-rise construction beyond the permissible height certified by the Civil Aviation Rules (CAR). As per the CAR, construction of Rangs can be permitted up to the $6^{\text {th }}$ floor. Rajuk issued an order to the plaintiffs to demolish the construction beyond $6^{\text {th }}$ floor within 10 days at the cost of the plaintiffs. Failure of this order would constitute the building becoming unauthorised and illegal. Rajuk did not receive any response from the plaintiffs within the stipulated time and hence, revoked the plan of the building.

The plaintiff then filed a case in the High Court Division of the Supreme Court, where the demolishing order was rejected. The judges in their verdict 
stated that the concerned authority (Rajuk) actually neglected the question of legality and/or propriety while adopting decision of canceling the permission of constructing the building. The plaintiffs neither breached any terms or conditions of the permission, nor made any incorrect statement for which permission can only be cancelled. The court emphasised that the construction undertaken so far, spending several millions of monetary costs and also as per the plan duly approved by Rajuk, must be held to be a property lawfully vested to the plaintiffs.

The defendants argued that the Air Force Head Quarter requested Rajuk to cancel the permission of the plaintiffs because the building was nearer to the approach path of the airport. Thus, the defendant repeatedly requested the plaintiff to obtain necessary clearance from Civil Aviation Authority (SAA). It is articulated further that when the 'Rangs Bhaban' was being constructed just 420 feet away from the approach path of the airport, the plaintiffs were obliged to take clearance from the CAA, but they did not. Resultantly, the defendant was left no option other than to direct the plaintiffs to demolish the excess height of the building.

The verdict of the High Court created a host of interesting questions. Should the adjacent airport stop its operations so that a high-rise building can be built? On what ground shall the owners of the building deny the appropriate rights of their property? The existence of the said building means the usual operation of the airport would be obstructed. The defendant then appealed to the Supreme Court, where the High Court decision was overturned.

Looking at the above lawsuit through the lens of Kersey vs. City of Atlanta, it can be stated that the High Court erred by rejecting Rajuk's order to demolish the impermissible height of the Rangs building. As per the first possession rule, the airport should possess the right to freely operate. Second, the High Court escaped the question as to whether the airport should be relocated because its proper operation was obstructed by the Rangs building, which in the court's eye preserved the right to stand high. The Supreme Court considered these facts and rightly overturned the High Court's order.

In the case of Kersey vs. City of Atlanta, the first-possession rule has created a dilemma: whether to ask Mr. Kersey to abandon his right to enjoy the peace and serenity because these features existed before the airport started its operation. However, asking the airport to relocate meant incurring 
an astounding amount of social cost. Thus, transaction cost was prioritised over the first-possession rule. However, in the case of A Rouf Chowdhury and another vs. Bangladesh and Others, the first-possession combined with the transaction cost made the Supreme Court's decision much easier.

We find a similar combination (first possession + transaction cost) in another case, Rahimafrooz Batteries Ltd vs. United Commercial Bank $L t d^{3}$. The plaintiff was the tenant of an abandoned property vested to the government of the Peoples Republic of Bangladesh. The government intended to dispose the property to private hands. Accordingly, the authority invited bids from individuals and commercial entities. Both the plaintiff and the defendant submitted their respective bids. All of a sudden, the plaintiff was served a notice asking to surrender the occupied property to the concerned authority because, according to the concerned authority's information, the defendant was accepted as the buyer of the property on the basis of the highest bid. In response, the plaintiff submitted an application offering to pay the amount equivalent to the highest bid. The concerned authority rejected the request. Instead, an eviction notice was issued. The plaintiff thus, prompted to file a suit on the Trial Court. Subsequently, the Trial Court examined whether the plaintiff got some pre-emptive rights to purchase the property. Upon proper investigation, the Trial Court decreed an order in favour of the plaintiff on the ground that the defendants were bound to sell the property to the plaintiff at an amount offered by the highest bidder. The defendant then appealed against the order in the appellate division of the High Court. The appellate division also held the trial court's verdict. The appellate division also argued in the same manner as the Trial Court but it emphasised on the pre-emptive right.

...we find that at the relevant time the plaintiff had got a legal right to sue against the defendant for purchasing the suit property with a pre-emptive right and the defendants are also bound to sell the property to the plaintiff following the policy of the government with regard to the disposal of the abandoned properties.

It is clear that the judges considered, besides preemptive rights, the economic consequences of alternative decisions. The plaintiff was already in possession of the said property by tenancy and already incurred a substantial amount of fixed investment. Thus, declaring the tenant's pre-emptive right void would 
mean the waste of the entire fixed investment of the plaintiff. On the other hand, the defendant was a fresh starter. If he does not have the opportunity to purchase the said land, he can simply find another suitable place and set up his business. This would save social costs.

\subsection{Attenuation of private property}

Property rights bestow owners with certain attributes in relation to an asset. Essential attributes comprise right to consume or benefit from the use of the asset, exclude others from uncompensated use of property, right to sale, dispose, or transfer of the asset, and also the right to derive income from the asset (Waldron, 1990; Munzer, 1990). The value of any property, therefore, depends on the degree to which owners of an asset can enjoy these attributes. For instance, several of the post-Communist countries placed restrictions on the sale of assets to foreign investors, which not only reduced exchangeability of assets but also the intrinsic value (Weimer, 1997). Likewise, restricting the use-right of an asset implies the attenuation of right on it, which is accompanied by the lower value of that property.

Transaction cost is an important determinant even in deciding whether attenuation of certain rights of the property owners can be accepted or not. In the case of Engineer Md. Nurul Islam Chowdhury vs. GM, Dhaka Rural Electrification Samity $1^{4}$, the plaintiff's rights were clearly attenuated by the government's action, which was declared illegal by the court.

The defendant is a regional body of Rural Electrification Board (REB), constituted under a government ordinance with the purpose of distribution of power in rural areas. In so doing, the REB constructs power distribution line and power sub-stations through Rural Electric Societies. In this lawsuit, the defendant set up a pole at the middle of the plaintiff's land. The plaintiff termed the erection as illegal and unauthorised and requested the defendants to remove the pole. Unless the pole is removed from the plot, the plaintiff cannot enjoy the full benefits of his property. The plaintiff specified that the erection of the pole had restricted his use rights. For example, if he wishes to build a multi-storied building, the pole is a barrier to this work. Despite this request, the defendant (REB) remained silent. As a result, the plaintiff was constrained to file the suit.

The court in its verdict stated that fixing the pole for electric overhead line in the petitioner's land is illegal and in violation of the fundamental 
rights of the plaintiff. The court thus, asked the defendant to remove the poles at its own cost.

This verdict is little bit at odds with the tradition of transaction cost, in the sense that the poles were set up in the said land to serve the greater interest of the public. As a result, prohibiting the defendant from exercising his due power to serve the nation. Moreover, if the pole is removed from the plaintiff's property, it has to be set up on another piece of land if REB wants to serve its purpose. The same problem may arise again. The court was not skeptical about this issue. It recognised the power of the defendant and clarified the applicable provision of law:

It also appears that though the respondents contended that they are empowered to place underground cables and overhead structures such as poles or wires for transmission of electricity on the land of the petitioners ... yet ... any land required for the Board may be requisitioned or acquired for the Board by the Government.

It is obvious that the plaintiff's property was not requisitioned or acquired by the defendant and erection of any poles was illegal per se. But the question remains, would the judges declare the activities legal once the Board acquires the said land? Perhaps the answer would be negative. Acquiring the said land saves the cost of transferring the poles. However, there is another important dimension of the problem. The plaintiff has already obtained permission as per the statute from the concerned authority for neighbouring a multi-storied building for which he had incurred monetary cost. Thus, the judges' view was that removing the poles and erecting it to the neighboring land would not make much difference for the society as a whole, but it would save enormous cost of the plaintiff. Moreover, as Coase (1960) mentioned, in the interpretation of words and phrases like 'reasonable' or 'common or ordinary use,' there are some recognitions of the economic aspects of the problems. The above verdict upholds this 'reasonable' interpretation of Coase.

An American case can be juxtaposed with the current one, which exemplifies same sort of government takings for public purpose. In the case of Lee County vs. Kiesel ${ }^{5}$, the Kiesel had purchased riverfront property and built a home on the land. The county then built a bridge that obstructed the Kiesels' view of the river from their property. Although the bridge did not 
physically encroach upon the property, Kiesel filed the suit, alleging that the county had taken their property without compensation. At trial, the plaintiffs' expert witness testified that the bridge's obstruction of the river view had reduced the property's value. The trial court found a taking, and the appellate court affirmed.

It is postulated from the case that even if the bridge was built for the greater interest of public, the resulting compensation was paid to the plaintiff equivalent to the reduced value of the property. It is interesting now to see why the court in the case of Engineer Md. Nurul Islam Chowdhury vs. GM, Dhaka Rural Electrification Samity 1 did not ask the defendant to pay compensation equivalent to the reduced value of the property. But rather, the court ordered for the outright removal of the poles. This is because the property value reduced by the erection of poles was so substantial that removing the poles and setting up at another low-value land by paying 'just' compensation was considered undoubtedly beneficial. On the other hand, shifting a bridge, even though not impossible, is impractical at least viewed in an economic sense.

\subsection{Transaction cost and public nuisance}

There are some instances in which transaction cost is considered in awarding the rights. In Bijoy Kumar Chakroborty vs. Md. Muzaffar Hossain ${ }^{6}$, the defendant-petitioner was trying to construct and start a cinema hall within the vicinity of the locality, which is a residential area comprising of temple, mosque, madrasha (institutions for Islamic education), and hostel to accommodate madrasha students. As such, the defendant tried to obtain a no-objection certificate from the concerned authority and duly obtained it. In this pursuit, the defendant started the construction on the proposed site. The plaintiff fielded the suit on the plea, that if the cinema hall is set up in the midst of a residential area, the social order of the area is prone to be disturbed and the peaceful atmosphere of public life will also be affected. The trial court decreed the suit. In an appeal, the same is affirmed. The petitioner then approached to the high court division where the rule was discharged. He then filed a petition in the appellate division of the high court, and the appellate division dismissed the petition. The division stated in its verdict: 
It would thus, appear that the licensing authority... has been vested by the statute with the discretion which is only subject to the control of government. But since the construction of a cinema house involved consideration of various other facts, such as the suitability of the site, its proximity to places of worship, the inconvenience likely to be caused to residents of the locality and other factors which were not specifically required by the Act to be taken into consideration for the purpose of license under the Act, the government can interfere even before commencing the construction of a cinema house at particular site.

Interestingly, the court mentioned the clause 'before commencing the construction,' which bears the intensity of the transaction cost. Since the cinema hall owner still did not sink significant cost for the construction, it was easy for the court to emphasise on such conditions such as social norms, customs, and values, which have been practiced over the years.

An interesting English case can be compared here. In the Adams vs. Uresell $^{7}$, the defendant is the owner of the fried-fish shop from which obnoxious smells spread in the adjacent area. The plaintiff filed a suit entitling the smell a nuisance in the residential part of that street. The defendant argued that an injunction imposed on his activities (selling fried fish in that residential area) will make a great hardship for his living. Moreover, the users, mainly the poor people of that locality, would be deprived from eating his cheap fish and chips. The judge then commented:

...it does not follow that the defendant cannot carry on his business in another more suitable place somewhere in the neighborhood. It by no means follows that because a fried fish shop is a nuisance in one place it is a nuisance in another.

The transaction cost argument in the above cases fits well because public nuisance is not always considered an abrogation of property rights. In the case of Sharif Nurul Ambia vs. Dhaka City Corporation ${ }^{8}$, the court found merely nuisance is not enough in imposing an injunction.

The plaintiff was an organizing member of a political party in Bangladesh, with his party office located in a renowned street of Dhaka. There was a vacant space that belonged to the Public Works Department 
(PWD) adjacent to the office of the plaintiff, which was assigned for construction of a public car parking centre. The PWD transferred the vacant space to the Dhaka City Corporation (DCC), which started earth-digging on the said land for the purpose of undertaking some construction for a multistoried shopping complex. However, after digging the said vacant space it was left open for a long time. Due to logging of rainwater and other abuses, the property turned into a small pond, and an obnoxious garbage depot started. This resulted in a threat to the healthy lifestyle in the neighbourhood. The plaintiff was constrained to file a complain in the High Court Division of the Supreme Court. The court stated that the temporary obnoxious smell from the proposed construction site does not construe any right to the plaintiff to ask for an injunction and to stop the construction. The question is whether sufficient care and general procedures have been maintained in the course of construction. The judge also argued:

If the construction is at all raised then only the question will arise as to whether the respondent has left sufficient space around the proposed building as prescribed for free flow of light and air and that inconvenience or discomfort for obstruction of light and air must be of substantial character to warrant a legal interference; the petitioner having not been able to produce sufficient material in order to establish his case the writ petition is premature.

Commenting on an English case, Andreae vs. Selfridge and Company Ltd. ${ }^{9}$, the Judge, Sir Wilfred Greene, M.R noted:

...when one is dealing with temporary operations, such as demolition and re-building, everybody has to put up with a certain amount of discomfort, because operations of that kind cannot be carried on at all without a certain amount of noise and a certain amount of dust. Therefore, the rule with regard to interference must be read subject to this qualification...

The High Court division declared that the rights of the plaintiff were not violated because of an obnoxious smell during its construction, and the court did not make any err. 


\section{Conclusion}

The field of law and economics has evolved as a hybrid discipline to bestow precision to the efficient analysis of legal issues. The field has challenged the conventional wisdom that judicial decision is merely a concern of social justice, morality, and fairness. In contrast, the economic analysis of legal verdicts shows that judges consider social cost in delivering the verdict regarding who owns what right. The field has been benefited from the seminal works of Ronald Coase. Primarily, the consideration of transaction cost has been noted in the case of initial allocation performed by the judicial system. Efficiency of resource allocation in the presence of high transaction cost is determined by the judicial system. The current paper has attempted to contribute to this strand of literature. In so doing, it has applied transaction cost theory as an analytical framework. Some legal cases collected from Bangladesh are analysed through the lens of the abovementioned framework.

The cases were chosen carefully so that they remain closely akin to some of the cases analysed by Coase. This has helped us assimilate our cases and sort out differences and similarities of the verdicts delivered. To facilitate the analysis, we have divided the cases into such sub-classes as firstpossession, attenuation of rights, and public nuisance. Our analysis shows that judges consider the economic aspects of the legal verdicts. Sometimes first possession does not guarantee owners to possess some rights of his/her property if the social cost favours the alternative arrangement. Similarly, attenuation of rights combined with the problem of social cost produces an entitlement of property rights. Nuisance alone may not be equivalent to takings if the social cost is absent. The analysis of the paper is expected to help policymakers, regulators, and legal practitioners in various ways, which are summarised below.

First, the conventional view is that the legal rulemaking rarely focuses on social cost because in deciding cases, the judges come across a set of rational choices where economic consequences are considered distant. However, the development of law and economics as a separate discipline and its rational approach to analyzing economic effects of judicial decisions show that social cost constitutes an integral element of judicial decisions, so far as efficiency is concerned. Hence, the finding of the paper provides an additional dimension for legal practitioners to consider the social cost 
of making laws and regulations. Second, some of our cases exhibit that the initial allocation was wrong because they ignored social costs. As a result, the court reversed the earlier allocation of rights. Based on this analysis, we have attempted to pinpoint economic elements that can render allocation of a particular right inefficient. Hence, the findings of our study provide the necessary ground that helps legislators avoid such inefficient allocations of rights in society. Third, the findings of this study highlight that initial allocation matters for efficiency if the transaction cost is high. Hence, the regulators can work on minimizing the overall transaction cost in the economy. This would facilitate the market transactions and hence, reduce the likelihood of inefficient allocation. Moreover, where transaction cost is high and cannot be avoided easily, a more efficient method of initial allocation can be considered.

\section{Note}

1 Supreme Court of Georgia. 193 Ga. 862, 20 S.E. 2d 245 (1942), reported in Coase (1960)

2 Dhaka Law Review (DLR) 52, 2000, (High Court Division)

3 Original decree no. 85 of 1997, Dhaka Law Report 52, 2000 (SC)

4 Writ petition number 4559 of 2002, DLR 58, 2006 (HC)

5 Lee County v. Kiesel, 705 So. 2d 1013 (Fla. Dist. Ct. App. 1998), reported in Biber (2000)

6 Civil revision no 4924 of 1998, DLR 58, 2005 (AD)

7 [1913] 1 Ch. 269, reported in Rogers (1994), Coase (1960)

8 Civil appeal no. 148 of 2002, DLR 58, 2004 (AD)

9 [1938] 1 Ch. 1, reported in Coase (1960)

\section{References}

Almlöf, H., \& Bjuggren, P. O. (2019). A regulation and transaction cost perspective on the design of corporate law. European Journal of Law and Economics, 47(3), 407-433. https://doi.org/10.1007/s10657-019-09620-x 
Berger, L. (1985). An analysis of the doctrine that "First in time is first in right." Nebraska Law Review, 64, 349-388.

Barrere, C. (2004). Judicial system and property rights, in Colombatto, E. (ed.), The Elgar Companion to the Economics of Property Rights, Edward Elgar: Cheltenham, UK, pp. 129-153.

Bertrand, E. (2006). The Coasean analysis of lighthouse financing: myths and realities. Cambridge Journal of Economics, 30(3), 389-402 https:// doi.org/10.1093/cje/bei068

Barzel, Y. (1997). Economic Analysis of Property Rights. Cambridge: Cambridge University Press.

Boyce, J. R. (1994). Allocation of goods by lottery. Economic Inquiry, 32(3), 457-476. https://doi.org/10.1111/j.1465-7295.1994.tb01343.x

Cai, Q. (2020). Economising international tax dispute resolution: transaction-cost perspective. Unpublished $\mathrm{PhD}$ dissertation, The University of Edinburgh. Retrieved from https://era.ed.ac.uk/bitstream/ handle/1842/36883/Cai2020.pdf?sequence=1.

Calabresi, G. (1961). Some thoughts on risk distribution and the law of torts. Yale Law Journal, 70(4), 499-553. https://doi.org/10.2307/794261

Candela, R. A., \& Geloso, V. (2019). Coase and transaction costs reconsidered: the case of the English lighthouse system. European Journal of Law and Economics, 48(3), 331-349. https://doi.org/10.1007/ s10657-019-09635-4

Cass, R. (2004). Property rights systems and the rule of law. In Colombatto, E. (ed.), The Elgar Companion to the Economics of Property Rights, Edward Elgar: Cheltenham, UK, pp. 222-250.

Coase, R. (1959). The Federal Communications Commission. Journal of Law and Economics, 2, 1-40, https://doi.org/10.1086/466549

Coase, R. (1960). The problem of social cost. Journal of Law and Economics, III, 1-44, 10.1057/9780230523210_6

Cooter, R. D., \& Rubinfeld, D. L. (1989). Economic analysis of legal disputes and their resolution. Journal of Economic Literature, 27(3), 1067-1097.

Cooter, R., \& Ulen, T. (2016). Law and Economics, $6^{\text {th }}$ edition. New York: Berkeley Law Books.

Demsetz, H. (1964). The exchange and enforcement of property rights. Journal of Law and Economics, 7, 11-26. https://doi.org/10.1086/466596 
Demsetz, H. (1966). Some aspects of property rights. Journal of Law and Economics, 9, 61-79. https://doi.org/10.1086/466619

Djørup, S. (2020). The institutionalisation of zero transaction cost theory: a case study in Danish district heating regulation. Evolutionary and Institutional Economics Review, 1-16. https://doi.org/10.1007/s40844020-00164-3

Dukeminier, J., \& Krier, J.E. (1993). Property (3rd ed). Boston: Little, Brown.

Ehrlich, I., \& Posner, R. A. (1974). An economic analysis of legal rulemaking. Journal of Legal Studies, 3(1), 257-286, https://doi. org/10.1086/467515

Ellickson, R. C. (1991). Order Without Law. Cambridge, MA: Harvard University Press.

Epstein, R. A. (1979). Possession as the root of title. Georgia Law Review 13, 1221-1243.

Epstein, L., \& Knight, J. (2017). The economic analysis of judicial behavior. In Epstein, L., and Lindquist, S. (eds.), The Oxford Handbook of US Judicial Behavior. New York: Oxford University Press, pp. 320-342.

Foray, D., \& Woerter, M. (2020). The formation of Coasean institutions to provide university knowledge for innovation: a case study and econometric evidence for Switzerland. Journal of Technology Transfer, 1-27. https://doi.org/10.1007/s10961-020-09828-z

Gao, L., Sun, D., \& Ma, C. (2019). The impact of farmland transfers on agricultural investment in China: A perspective of transaction cost economics. China \& World Economy, 27(1), 93-109. https://doi. org/10.1111/cwe.12269

Hahn, R. W., \& Stavins, R. N. (2011). The effect of allowance allocations on cap-and-trade system performance. Journal of Law and Economics, 54(4), 267-294. https://doi.org/10.1086/661942

Hylton, K. N. (2019). Law and economics versus economic analysis of law. European Journal of Law and Economics, 48(1), 77-88. https://doi. org/10.1007/s10657-018-9580-0

Jolls, C., Sunstein, C. R., \& Thaler, R. (1998). A behavioral approach to law and economics, Stanford Law Review, 50, 1471-1550. https://doi. org/10.2307/1229304

Kaplow, L. (1986). An economic analysis of legal transitions. Harvard Law Review, 99(3), 509-617. https://doi.org/10.2307/1341148 
Kaplow, L., \& Shavell, S. (1994). Why the legal system is less efficient than the income tax in redistributing income. Journal of Legal Studies, 23(2), 667-681. https://doi.org/10.1086/467941

Kornhauser, L. A. (1985). An introduction to the economic analysis of contract remedies, University of Colorado Law Review, 57, 683-720.

Libecap, G. D. (1989). Distributional issues in contracting for property rights. Journal of Institutional and Theoretical Economics, 145, 6-24.

McCluskey, M. T., Pasquale, F., \& Taub, J. (2016). Law and economics: Contemporary approaches. Yale Law \& Policy Review, 35, 297-308.

Milgrom, P. (2004). Putting Auction Theory to Work. Cambridge: Cambridge University Press.

Milgrom, P. R., \& Weber, R. J. (1982). A theory of auctions and competitive bidding. Econometrica, 50(5), 1089-1122. https://doi. org/10.2307/1911865

Mundaca T, L., Mansoz, M., Neij, L., \& Timilsina, G. R. (2013). Transaction costs analysis of low-carbon technologies. Climate Policy, 13(4), 490513. https://doi.org/10.1080/14693062.2013.781452

Munzer, S. R. (1990). A Theory of Property. Cambridge: Cambridge University Press.

North, D. (1990). Institutions, Institutional Change and Economic Performance. Cambridge: Cambridge University Press.

Polinsky, A. M. (2019). An Introduction to Law and Economics. New York: Wolters Kluwer Law \& Business.

Posner, E. A. (2002). Economic analysis of contract law after three decades: Success or failure. Yale Law Journal, 112, 829-880.

Posner, R. A. (1973). An economic approach to legal procedure and judicial administration. Journal of Legal Studies, 2(2), 399-458. https://doi. org/10.1086/467503

Rose, C. M. (1985). Possession as the origin of property. University of Chicago Law Review, 53, 73-88. https://doi.org/10.2307/1599571

Slaev, A. D., \& Daskalova, D. (2020). Complex property rights and Coasean bargaining in natural resource management. Journal of Environmental Policy \& Planning, 22, 486-500. https://doi.org/10.1080/152390 8X.2020.1768833

Taylor, G. A., Tsui, K. K., \& Zhu, L. (2003). Lottery or waiting-line auction? Journal of Public Economics, 87(5-6), 1313-1334. https://doi. org/10.1016/S0047-2727(01)00196-7 
Waldron, J. (1990). The Right to Private Property. Oxford: The Clarendon Press.

Weimer, David. 1997. The Political Economy of Property Rights: Institutional Change and Credibility in the Reform of Centrally Planned Economies. Cambridge: Cambridge University Press.

Womble, P., \& Hanemann, W. M. (2020). Legal change and water market transaction costs in Colorado. Water Resources Research, 56(4). https:// doi.org/10.1029/2019WR025508 